\title{
ANALISIS KLASTER PAUTAN LENGKAP UNTUK MENGELOMPOKKAN KABUPATEN/KOTA DI PROVINSI SULAWESI TENGAH BERDASARKAN INDIKATOR KRIMINALITAS
}

\author{
I. T. Utami ${ }^{1}$, Rais ${ }^{2}$, dan W. Seftiani ${ }^{3}$ \\ 1,2,3Program Studi Statistika Jurusan Matematika FMIPA Universitas Tadulako \\ Jalan Soekarno-Hatta Km. 09 Tondo, Palu 94118, Indonesia. \\ 1triutami.iut@gmail.com, 2rais76_untad@yahoo.co.id, 3wzeftiani@gmail.com
}

\begin{abstract}
Criminality is all kinds of actions and deeds which is economically and psychologically harmful. The statistical method could be used to classify the crime is cluster analysis. Cluster analysis is a multivariate method which aims to classify a sample of subjects (or objects) on the basis of a set of measured variables into a number of different groups such that similar subjects are placed in to the same group. The objective of this research is to classify Regency/City in Central Sulawesi Province based on the criminality indicator and to discover the profile of each cluster which had been formed. The results of the study shows that those are two clusters formed: Cluster 1 consists of Buol, Banggai, Morowali, Toli-Toli, Donggala, and Tojo Una-Una Regency; Cluster 2 consists of Regency/Palu City, and Parigi Moutong. The profile of each cluster is: Cluster 1 with low crime rate on average and Cluster 2 with high crime rate on average.
\end{abstract}

Keywords $\quad$ : Cluster Analysis, Complete Linkage, Criminality, Hierarchy Method.

\begin{abstract}
ABSTRAK
Kriminalitas merupakan segala macam bentuk tindakan dan perbuatan yang merugikan secara ekonomi dan psikologis. Metode statistika yang dapat digunakan untuk mengelompokkan tindak kriminalitas adalah analisis klaster, yaitu suatu teknik multivariat yang bertujuan memisahkan obyek ke dalam beberapa kelompok yang mempunyai sifat berbeda antar kelompok yang satu dengan yang lain. Tujuan dari penelitian ini adalah untuk mengelompokkan Kabupaten/Kota di Provinsi Sulawesi Tengah berdasarkan indikator kriminalitas dan mengetahui profil dari setiap klaster yang telah terbentuk. Hasil dari penelitian ini menunjukkan terdapat 2 klaster yang terbentuk: Klaster 1 terdiri dari Kabupaten Buol, Banggai, Morowali, Toli-Toli, Donggala dan Tojo Una-Una; Klaster 2 terdiri dari Kabupaten/Kota Palu dan Parigi Moutong. Profil dari setiap klaster yaitu: Klaster 1 dengan rata-rata tingkat kejahatan rendah dan Klaster 2 dengan rata-rata tingkat kejahatan tinggi.
\end{abstract}

Kata kunci : Analisis Klaster, Pautan Lengkap, Kriminalitas, Metode Hirarki. 


\section{PENDAHULUAN}

\subsection{Latar Belakang}

Rasa aman merupakan kebutuhan manusia yang penting. Menurut (Maslow, dalam BPS Jakarta-Indonesia, 2014) rasa aman berada pada tingkatan yang di bawah kebutuhan dasar manusia seperti sandang, pangan, dan papan. Hal ini menunjukkan bahwa rasa aman merupakan salah satu hak asasi yang harus diperoleh atau dinikmati setiap orang. Sulawesi Tengah sebagai salah satu provinsi yang terus berkembang. Politik, ekonomi, sosial budaya sarat dengan berbagai masalah kompleks yang dapat menjadi tempat tumbuh subur dan berkembangnya berbagai kejahatan (BPPD dan PMKP, 2014).

Data selang waktu terjadinya tindak pidana tahun 2009-2011 dan pelaku tindak kejahatan menurut klasifikasi umur dan jenis kelamin tahun 2011 dalam buku Statistik Politik dan Keamanan Sulawesi Tengah 2013 yang dipublikasikan oleh (BPS Sulteng, 2014) menunjukkan Kota Palu memiliki intensitas tindak pidana yang paling tinggi di Sulawesi Tengah, dan Kabupaten Toli-toli dengan intensitas tindak pidana paling rendah, dan untuk pelaku tindak pidana terbanyak adalah lelaki dewasa, serta terdapat pula pelaku lelaki anakanak dalam melakukan tindak kejahatan.

Salah satu upaya untuk mengukur rasa aman masyarakat dengan melakukan pengelompokan untuk melihat statistik dan indikator yang biasa digunakan, semakin tinggi angka kriminalitas menunjukkan semakin banyak tindak kejahatan pada masyarakat yang merupakan indikasi bahwa masyarakat merasa semakin tidak aman (BPS, JakartaIndonesia, 2014). Dalam IImu Statistika, analisis klaster adalah suatu teknik multivariat yang bertujuan memisahkan obyek ke dalam beberapa kelompok yang mempunyai sifat berbeda antar kelompok yang satu dengan yang lain (Prayudho, 2009).

Penelitian yang dilakukan (Febriana, 2014) dalam kasus kesehatan dengan Judul Kinerja Metode Complete Linkage, Metode Average Linkage, dan Metode K-Means Dalam Menentukan Hasil Analisis Klaster, didapatkan hasil bahwa metode complete lingkage dan average lingkage adalah metode yang terbaik dari ketiga metode yang diteliti. Sedangkan penelitian (Kurniawan, 2012) dengan judul Analisis Pengelompokan Jenis Kejahatan pada kasus kriminalitas di Provinsi DKI Jakarta Tahun 2012, hasil pengelompokan jenis kejahatan yang paling rawan di provinsi DKI Jakarta menggunakan metode korespondensi, analisis faktor, analisis pseudo $f$ dan perbandingan dalam analisis klaster metode hirarki yaitu single linkage, complete linkage, dan average linkage mendapatkan metode terbaik yaitu complete linkage. 
Metode complete lingkagel furthest neighbor atau disebut Pautan lengkap pada kedua penelitian sebelumnya adalah metode hirarki yang jumlah kelompok belum ditentukan dalam penelitian, pautan lengkap (complete linkage) diketahui metode tersebut dapat memberikan hasil dengan klaster terkecil. Metode pautan lengkap disebut juga pendekatan tetangga terjauh dengan berdasar pada jarak maksimum, dalam metode ini, seluruh objek dalam suatu klaster dikaitkan satu sama lain pada suatu jarak maksimum atau dengan kesamaan minimum (Prayudho, 2009).

Melihat hasil yang dicapai dari kedua metode yang digunakan (Febriana, 2014) dan (Kurniawan, 2012) memunculkan ide penulis untuk mengkhususkan penelitian yaitu menggunakan analisis klaster dengan metode hirarki pautan lengkap dalam kasus kriminalitas dengan daerah di Provinsi Sulawesi Tengah. Dalam kasus penelitian ini, variabel yang akan diteliti adalah pengelompokan kejahatan berdasarkan buku Statistik Politik dan Keamanan Sulawesi Tengah, 2015/2016 yang dipublikasikan oleh (BPS Sulteng, 2016) sebagai berikut: pembunuhan, penganiayaan berat, penganiayaan ringan, perkosaan, penculikan, pencurian, pencurian dengan pemberatan, pencurian kendaraan bermotor, pengrusakan/ penghancuran barang, pembakaran dengan sengaja, penadahan, dan pencurian lainnya.

\subsection{Rumusan Masalah}

Berdasarkan latar belakang di atas, perumusan masalah dalam skripsi ini adalah:

1. Bagaimana cara mengklaster/ mengelompokkan 8 (delapan) Kabupaten/ Kota di Provinsi Sulawesi Tengah berdasarkan indikator kriminalitas dengan menggunakan metode hirarki pautan lengkap dalam analisis klaster?

2. Bagaimana profil klaster/pengelompokkan dari setiap klaster yang telah terbentuk?

\subsection{Batasan Masalah}

Dalam penelitian ini, metode yang digunakan adalah analisis klaster dengan pendekatan hirarki pautan lengkap (complete lingkage), sedangkan data yang diambil adalah data pengelompokan kejahatan berdasarkan Statistik Politik dan Keamanan Sulawesi Tengah Tahun 2015/2016 untuk 8 (delapan) Kabupaten/Kota dari 13 kabupaten/kota yang ada di Provinsi Sulawesi Tengah, yaitu: Kabupaten/Kota Palu, Banggai, Morowali, Donggala, Tolitoli, Buol, Parigi Moutong, dan Tojo Una-Una dengan 15 variabel kejahatan yaitu: pembunuhan, perkosaan, penadahan, pengrusakan/penghancuran penganiayaan ringan, penganiayaan berat, penculikan, pembakaran dengan sengaja, , pencurian dengan pemberatan, pencurian ringan, pencurian dengan kekerasan, pencurian dalam keluarga, penipuan/perbuatan curang, pencurian kendaraan bermotor, dan pencurian lainnya. 


\section{PROSEDUR PENELITIAN}

Prosedur dalam penelitian ini adalah:

1. Melakukan studi literatur dengan mengumpulkan materi dan dari buku-buku, artikel, dan jurnal yang didapatkan dari perpustakaan dan internet.

2. Menganalisa masalah

3. Memulai penelitian

4. Mengambil data

5. Melakukan proses standarisasi data

6. Mengukur kemiripan dan ketakmiripan obyek menggunakan jarak euclidean

7. Mengelompokkan dengan analisis klaster pautan lengkap

8. Interpretasi dan profil kelompok

9. Selesai.

\section{HASIL DAN PEMBAHASAN}

\subsection{Data Penelitian}

Dari 13 kabupaten/kota terdapat beberapa kabupaten/kota yang tidak memiliki data dari variabel jenis tindak kriminalitas yang akan diolah, hal tersebut disebabkan beberapa wilayah belum memiliki kantor Kepolisian Resor (Polres), hal inilah yang mendasari data penelitian hanya terdiri dari 8 kabupaten/kota di Provinsi Sulawesi Tengah. Tabel 1 menunjukkan data kriminalitas di 8 Kabupaten/Kota di Provinsi Sulawesi Tengah berdasarkan indikator kriminalitas.

Tabel 1 : Data frekuensi kriminalitas 8 Kabupaten/Kota di Provinsi Sulawesi Tengah

\begin{tabular}{|c|c|c|c|c|c|c|c|c|c|c|c|c|c|c|c|c|}
\hline Obyek & KAB & $\mathbf{X 1}$ & $\mathbf{X 2}$ & $\mathbf{X 3}$ & $\mathbf{X} 4$ & $\mathbf{X 5}$ & $\mathbf{X 6}$ & $\mathbf{X 7}$ & $\mathbf{X 8}$ & $\mathbf{X 9}$ & $\mathbf{X 1 0}$ & $\mathbf{X 1 1}$ & $\mathbf{X 1 2}$ & $\mathbf{X 1 3}$ & $\mathbf{X 1 4}$ & $\mathbf{X 1 5}$ \\
\hline 1 & Banggai & 0 & 4 & 6 & 0 & 0 & 0 & 42 & 38 & 0 & 7 & 0 & 104 & 0 & 89 & 70 \\
\hline 2 & Morowali & 0 & 0 & 0 & 1 & 0 & 4 & 33 & 0 & 0 & 0 & 0 & 37 & 0 & 10 & 97 \\
\hline 3 & Donggala & 5 & 1 & 0 & 6 & 1 & 0 & 35 & 80 & 10 & 1 & 4 & 43 & 0 & 6 & 48 \\
\hline 4 & Toli-toli & 1 & 0 & 0 & 0 & 3 & 0 & 3 & 42 & 0 & 4 & 0 & 14 & 0 & 0 & 19 \\
\hline 5 & Buol & 1 & 6 & 0 & 0 & 0 & 1 & 28 & 0 & 0 & 0 & 0 & 37 & 0 & 0 & 108 \\
\hline 6 & Parigi Moutong & 10 & 5 & 0 & 0 & 0 & 6 & 68 & 25 & 0 & 5 & 6 & 73 & 0 & 0 & 205 \\
\hline 7 & Tojo Una-Una & 0 & 2 & 5 & 21 & 0 & 1 & 15 & 0 & 7 & 0 & 0 & 37 & 1 & 23 & 46 \\
\hline 8 & Palu & 6 & 3 & 1 & 0 & 0 & 2 & 71 & 570 & 0 & 213 & 6 & 117 & 0 & 871 & 391 \\
\hline
\end{tabular}

Keterangan :

$\mathrm{X} 1$ : Pembunuhan

X2 : Perkosaan

X3 : Penganiayaan Ringan

$\mathrm{X} 4$ : Penganiayaan Berat

X5 : Penculikan

X6 : Pembakaran dengan Sengaja 
$\mathrm{X} 7$ : Pengrusakan/ Penghancuran

$X 8$ : Pencurian dengan Pemberatan

$X 9$ : Pencurian Ringan

X10: Pencurian dengan Kekerasan

X11: Pencurian dalam Keluarga

X12: Penipuan/Perbuatan Curang

X13: Penadahan

X14 :Pencurian Kendaraan Bermotor

X15: Pencurian Lainnya

\subsection{Pengelompokan dengan Metode Analisis Klaster Pautan Lengkap}

\subsubsection{Standarisasi Data}

Proses standarisasi menjadikan dua data dengan perbedaan satuan yang lebar akan otomatis menjadi menyempit.

$z(X 1)=\frac{0-2,88}{3,720}=-0,77$

Untuk X2, $\cdots$, X15 nilai z-skor tidak ditampilkan. Dari hasil keseluruhan perhitungan zskor, diketahui rata-rata nilai z-skor mendekati 0 yang menunjukkan bahwa skor dekat dengan mean populasi dan karena itu representatif. Selanjutnya hasil keseluruhan nilai standarisasi data kemudian dipakai untuk mengukur kemiripan dan ketakmiripan objek.

\subsubsection{Mengukur Kemiripan dan Ketakmiripan Objek}

Jarak yang digunakan dalam penelitian ini adalah jarak euclidean. Jarak ini digunakan sebagai dasar untuk mengelompokkan kesamaan skor dari data yang dianalisis, sehingga peneliti akan dapat menentukan kabupaten mana yang masuk kelompok yang mana. Semakin kecil jarak euclidean, maka semakin mirip kedua variabel tersebut sehingga akan membentuk klaster. Tabel 2 menunjukkan matriks kedekatan dari perhitungan jarak Euclidean.

Tabel 2 : Matriks Kedekatan

\begin{tabular}{|l|c|c|c|c|c|c|c|c|}
\hline \multirow{2}{*}{ Kabupaten } & \multicolumn{7}{|c|}{ Jarak Euclidean } \\
\cline { 2 - 9 } & $\begin{array}{l}\text { 1:Bang } \\
\text { yai }\end{array}$ & $\begin{array}{l}\text { 2:Morowal } \\
\mathrm{i}\end{array}$ & $\begin{array}{l}\text { 3:Donggal } \\
\text { a }\end{array}$ & $\begin{array}{l}\text { 4:Tolitol } \\
\mathrm{i}\end{array}$ & 5:Buol & $\begin{array}{l}\text { 6:Parigi } \\
\text { utong }\end{array}$ & $\begin{array}{l}\text { 7:Tojo Una- } \\
\text { Una }\end{array}$ & 8:Palu \\
\hline 1:Banggai & .000 & 3.987 & 4.699 & 5.089 & 3.279 & 5.331 & 5.013 & 6.516 \\
2:Morowali & 3.987 & .000 & 3.905 & 3.713 & 3.008 & 4.631 & 5.080 & 6.924 \\
3:Donggala & 4.699 & 3.905 & .000 & 4.036 & 4.063 & 5.006 & 4.763 & 6.858 \\
4:Tolitoli & 5.089 & 3.713 & 4.036 & .000 & 4.149 & 6.572 & 5.730 & 8.126 \\
5:Buol & 3.279 & 3.008 & 4.063 & 4.149 & .000 & 4.504 & 5.187 & 6.855 \\
6:Parigi & 5.331 & 4.631 & 5.006 & 6.572 & 4.504 & .000 & 7.043 & 5.759 \\
ng & & & & & & & & \\
\hline
\end{tabular}




\begin{tabular}{|l|l|l|l|l|l|l|l|l|} 
7:Tojo Una- & 5.013 & 5.080 & 4.763 & 5.730 & 5.187 & 7.043 & .000 & 8.501 \\
8:Palu & 6.516 & 6.924 & 6.858 & 8.126 & 6.855 & 5.759 & 8.501 & .000 \\
\hline
\end{tabular}

\subsection{Proses Pengelompokan}

\subsubsection{Proses aglomerasi menggunakan metode pautan lengkap}

Aglomerasi adalah bagian yang sangat penting pada saat mencoba interprestasi analisis klaster hirarki. Proses aglomerasi bersifat kompleks, khususnya perhitungan koefisien yang melibatkan sekian banyak obyek dan terus bertambah. Proses aglomerasi pada akhirnya akan menyatukan semua obyek menjadi satu klaster. Hanya saja dalam prosesnya dihasilkan beberapa klaster dengan masing-masing anggotanya, tergantung jumlah klaster yang terbentuk. Tabel 3 merupakan hasil proses klaster skedul aglomerasi dengan metode complete lingkage (pautan lengkap). Setelah jarak antar variabel diukur dengan jarak euclidean, maka dilakukan pengelompokan yang dilakukan secara bertingkat.

Tabel 3 : Proses Aglomerasi

\begin{tabular}{|c|c|c|c|c|c|c|}
\hline \multirow[t]{2}{*}{ Stage } & \multicolumn{2}{|c|}{ Kombinasi Klaster } & \multirow[t]{2}{*}{ Koefisien } & \multicolumn{2}{|c|}{ Stage Cluster First Appears } & \multirow[t]{2}{*}{ Next Stage } \\
\hline & Klaster 1 & Klaster 2 & & Klaster 1 & Klaster 2 & \\
\hline 1 & 2 & 5 & 3.008 & 0 & 0 & 2 \\
\hline 2 & 1 & 2 & 3.987 & 0 & 1 & 4 \\
\hline 3 & 3 & 4 & 4.036 & 0 & 0 & 4 \\
\hline 4 & 1 & 3 & 5.089 & 2 & 3 & 5 \\
\hline 5 & 1 & 7 & 5.730 & 4 & 0 & 7 \\
\hline 6 & 6 & 8 & 5.759 & 0 & 0 & 7 \\
\hline 7 & 1 & 6 & 8.501 & 5 & 6 & 0 \\
\hline
\end{tabular}

\subsubsection{Dendogram}

Dendogram berguna untuk menunjukkan anggota klaster yang ada. Proses penggabungan dimulai pada skala 0 , dan variabel-variabel yang terwakili dengan garis tersebut semakin mungkin membentuk sebuah klaster. Proses penggabungan berjalan ke-arah kanan, dengan menggunakan petunjuk panjang garis yang semakin ke kanan, hingga pada akhirnya semua variabel akan tergabung menjadi satu klaster. Output dendogram dalam penelitian ini dapat dilihat pada Gambar 1 : 


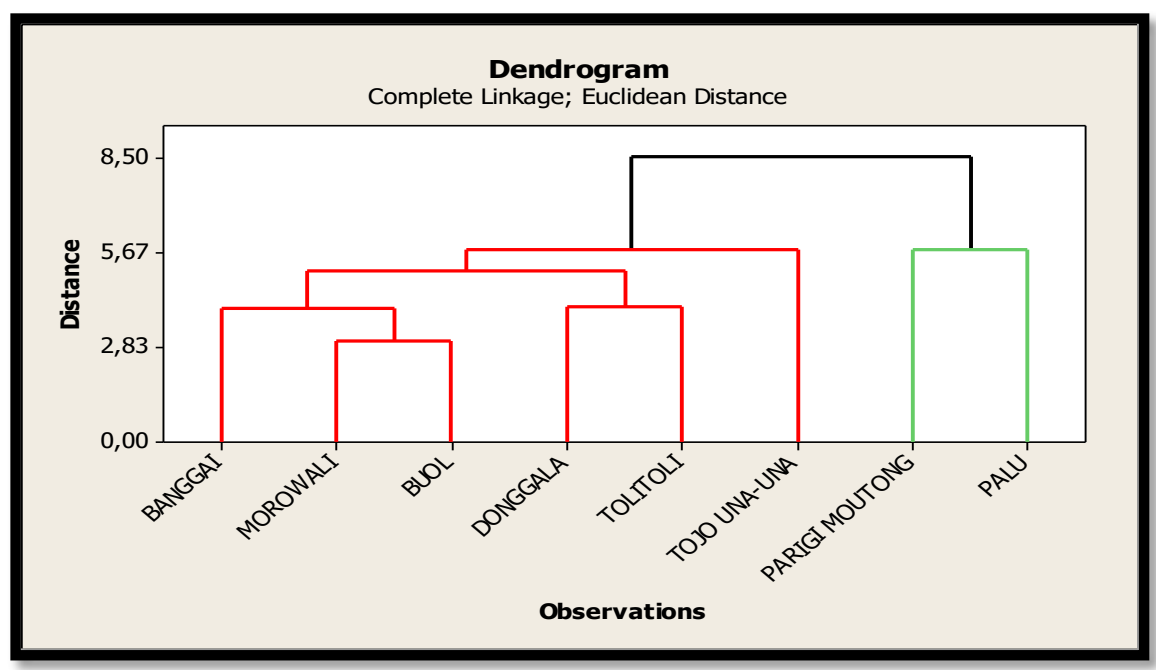

Gambar 1 : Dendogram Pengelompokan

Dari Gambar 1 Output Dendogram dengan jarak minimum $d=3,008$ menggabungkan Kabupaten Morowali dan Buol, kemudian Kabupaten Banggai membentuk sebuah klaster tersendiri dengan jarak 3,987 yang terdekat dengan Kabupaten Morowali sehingga panjang garis ketiga obyek pun tergabung menjadi satu kesatuan. Begitu pula dengan Kabupaten Donggala dan Toli-Toli, masing-masing membentuk satu klaster tersendiri dengan jarak 4,036. Kemudian, terlihat obyek Kabupaten Tojo Una-una yang menggabungkan seluruh obyek menjadi satu klaster dengan jarak 5,730, selanjutnya Kabupaten Parigi Moutong, dan Kota Palu hanya berdiri sendiri atau tidak tergabung dengan variabel lainnya dengan jarak yang menggabungkan kedua obyek adalah 5,759. Sehingga diperoleh dua klaster dengan nilai cut offyang menggabungkan seluruh obyek adalah jarak 8,501 .

\subsection{Interpretasi dan Pembuatan Profil Kelompok}

Rata-rata setiap variabel memungkinkan untuk memberikan label pada setiap klaster. yaitu rata-rata semua indikator jenis tindak kejahatan pada 8 kabupaten/kota di Provinsi Sulawesi Tengah akan dibandingkan dengan rata-rata kelompok kabupaten/kota yang terbentuk dari proses pengklasteran atau pengelompokan. Dari rata-rata keseluruhan variabel pada tiap klaster, dapat diketahui bahwa klaster 1, yang terdiri dari Kabupaten Morowali, Buol, Banggai, Donggala, dan Toli-toli memiliki rata-rata 13,41; sedangkan klaster 2, yang terdiri dari Kabupaten Parigi Moutong dan Kota Palu memiliki nilai rata-rata 88,46, yang artinya lebih tinggi dibandingkan klaster 1 , sehingga dapat diprofilkan bahwa klaster 1 (dengan rata-rata rendah) atau dapat didefinisikan tindak kejahatan/kriminalitas rendah, dan klaster 2 (dengan rata-rata tinggi) atau dapat didefinisikan tindak kejahatan/kriminalitas tinggi. Pada penelitian ini interpretasi dan pembuatan profil ditunjukkan pada Tabel 4. 
Tabel 4 : Rata-rata klaster dari seluruh variabel

\begin{tabular}{|c|c|c|}
\hline Klaster yang terbentuk & Kabupaten & Rata-rata variabel \\
\hline \multirow{6}{*}{ Klaster 1} & Morowali & \multirow{6}{*}{13,41} \\
\hline & Buol & \\
\hline & Banggai & \\
\hline & Donggala & \\
\hline & Toli-toli & \\
\hline & Tojo Una-Una & \\
\hline \multirow{2}{*}{ Klaster 2} & Palu & \multirow{2}{*}{88,46} \\
\hline & Parigi Moutong & \\
\hline
\end{tabular}

Dengan karakteristik pengelompokan dapat dilihat dari keseluruhan variabel pada Gambar 2 dan Gambar 3 :

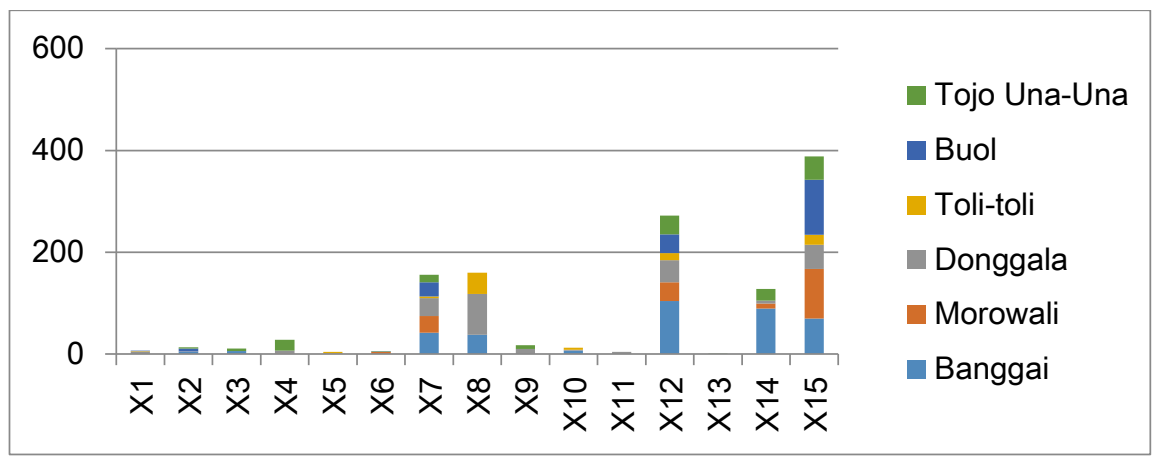

Gambar 2 : Column chart keseluruhan variabel klaster 1

Dari Gambar 2 dapat dilihat klaster 1 tergabung berdasarkan variabel yang paling tinggi adalah X15 (pencurian lainnya), dan ciri dari klaster 1 adalah rata-rata obyek memiliki keseluruhan jenis kejahatan, kecuali variabel X13 (penadahan).

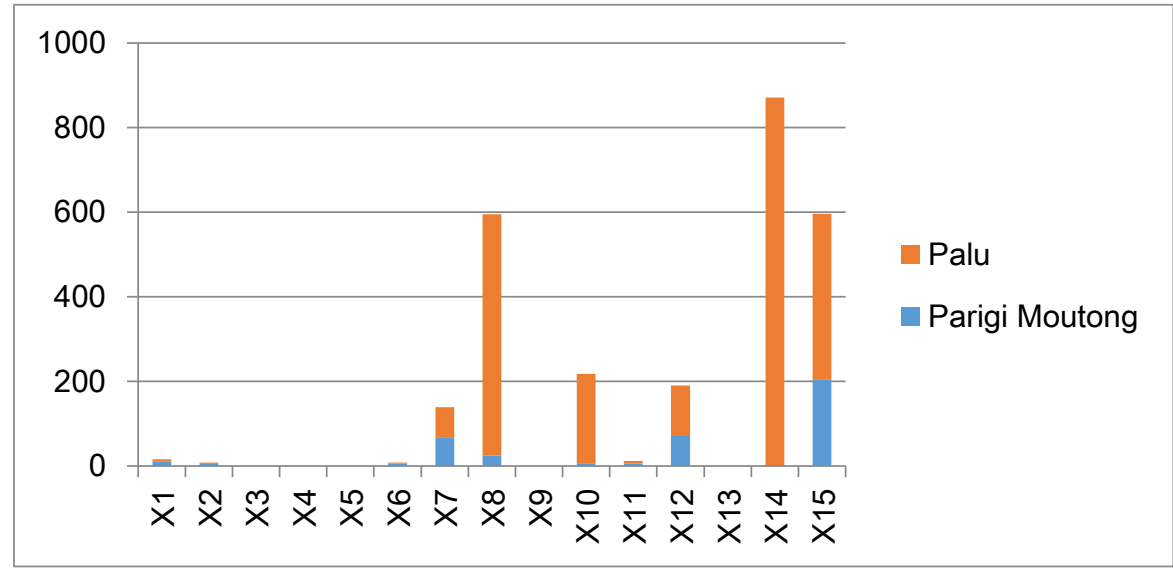

Gambar 3 : Column chart keseluruhan variabel klaster 2 
Dari Gambar 3 dapat dilihat klaster 2 tergabung berdasarkan variabel yang paling tinggi adalah X15 (pencurian lainnya), selanjutnya X12 (penipuan/ perbuatan curang), X7 (pengrusakan/penghancuran), $\quad X 8$ (pencurian dengan pemberatan), kemudian $X 1$ (pembunuhan), dan ciri dari klaster 1 adalah rata-rata obyek tidak memiliki variabel $X 3$ (penganiayaan ringan), X4 (penganiayaan berat), X5 (penculikan), X9 (pencurian ringan), dan X13 (penadahan). Rata-rata tiap klaster diilustrasikan dalam peta pada Gambar 4 :

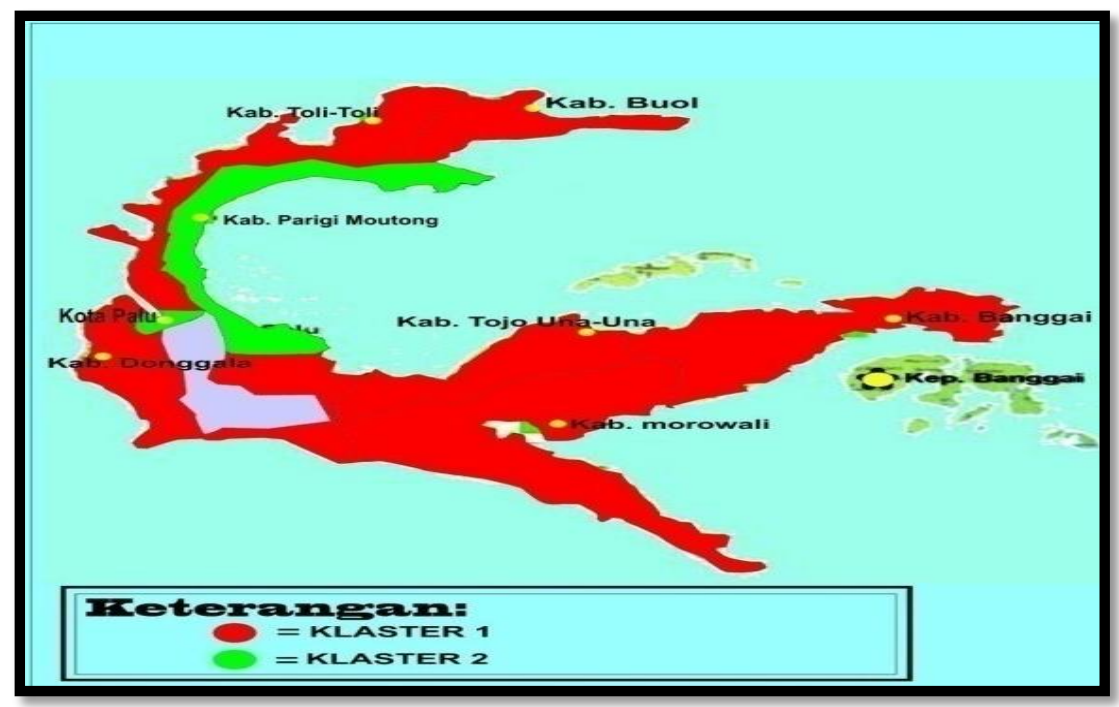

Gambar 4 : Peta hasil klaster dan profil kelompok

\section{KESIMPULAN}

Berdasarkan hasil dan pembahasan pada bab sebelumnya, kesimpulan yang diperoleh adalah sebagai berikut :

1. Dari hasil pengklasteran/ pengelompokan dengan menggunakan metode hirarki pautan lengkap terhadap 8 Kabupaten/Kota di Provinsi Sulawesi Tengah, maka didapatkan 2 klaster: Klaster 1 terdiri dari : Kabupaten Buol, Kabupaten Banggai, Kabupaten Morowali, Kabupaten Tolitoli, Kabupaten Donggala, dan Kabupaten Tojo Una-Una. Klaster 2 terdiri dari: Kabupaten/Kota Palu dan Kabupaten Parigi Moutong.

2. Dari hasil proses klaster 8 (delapan) Kabupaten/Kota di Provinsi Sulawesi Tengah menggunakan analisis klaster pautan lengkap, dapat diketahui profil dari setiap klaster yang terbentuk, yaitu: Klaster 1 dengan rata-rata tingkat kejahatan rendah. Tergabung berdasarkan variabel yang paling tinggi adalah X15(pencurian lainnya), dan ciri dari klaster 1 adalah ratarata obyek memiliki keseluruhan jenis kejahatan, kecuali variabel X13 (penadahan). Klaster 2 dengan rata-rata tingkat kejahatan tinggi. Tergabung berdasarkan variabel yang paling tinggi adalah X15 (pencurian lainnya), selanjutnya X12 (penipuan/ perbuatan curang), X7 
(pengrusakan/ penghancuran), $\mathrm{X} 8$ (pencurian dengan pemberatan), kemudian $\mathrm{X} 1$ (pembunuhan), dan ciri dari klaster 2 adalah rata-rata obyek tidak memiliki variabel $X 3$ (penganiayaan ringan), $X 4$ (penganiayaan berat), X5 (penculikan), X9 (pencurian ringan), dan X13 (penadahan).

\section{DAFTAR PUSTAKA}

[1] BPPD dan PMKP Badan Perencanaan Pembangunan Daerah dan Penanaman Modal Kota Palu, Profil Daerah Kota Palu 2014, 2014, Palu.

[2] BPS Badan Pusat Statistik Jakarta - Indonesia, Statistik Kriminal 2014, 2014, Jakarta.

[3] BPS Badan Pusat Statistik Sulawesi Tengah, Statistik Politik dan Keamanan Provinsi Sulawesi Tengah 2014, 2014, Sulawesi Tengah.

[4] BPS Badan Pusat Statistik Sulawesi Tengah, Statistik Politik dan Keamanan Provinsi Sulawesi Tengah 2015/2016, 2016, Sulawesi Tengah.

[5] Prayudho, B.J., Analisis Cluster. Diperoleh dari website Pribadi Prayudho:https://prayudho.wordpress.com/2009/12/30/analisis-cluster, 2009.

[6] Kurniawan, R.E., Analisis Pengelompokan Jenis Kejahatan Pada Kasus Kriminalitas di Provinsi DKI Jakarta Tahun 2012, Skripsi, Fakultas Matematika dan IImu Pengetahuan Alam, Institut Teknologi Sepuluh November, http://digilib.its.ac.id/public/lTS-paper31730-1310030051-Presentation.pdf, 2012, Surabaya.

[7] Febriana, L.T., Perbandingan Kinerja Metode Complete Linkage, Metode Average Linkage, dan Metode K-Means dalam Menentukan Hasil Analisis Klaster, Skripsi, Matematika, Fakultas Matematika dan IImu Pengetahuan Alam Universitas Negeri Yogyakarta, http://eprints.uny.ac.id/id/eprint/12549, 2014, Yogyakarta. 